\title{
IMPLEMENTASI STRATEGI PEMBELAJARAN PQ4R UNTUK MENINGKATKAN KEMAMPUAN MENGINGAT MAHASISWA
}

\author{
Anita rahmawati \\ Pendidikan Biologi, Sekolah Tinggi Keguruan dan Ilmu Pendidikan (STKIP) Bima \\ anitarahmawati909@gmail.com
}

\begin{abstract}
ABSTRAK
Penelitian ini bertujuan untuk mengetahui peningkatan kemampuan mengingat mahasiswa dengan mengimplementasikan strategi pembelajaran PQ4R. Penelitian ini merupakan penelitian tindakan kelas yang terdiri dari siklus I dan siklus II. Data tentang kemampuan mengingat mahasiswa diperoleh melalui tes yang dialkukan tiap ahir siklus. Tersebut berupa soal uraian. Hasil tes tersebut kemudian dianalisis dengan menghitung ketuntasan individu dan ketuntasan klasikal. Dari analisis data diperoleh porsentase ketuntasan klasikal pada siklus I 43,4\% dengan perolehan nilai tertinggi 86 dan nilai terendah 34 dan meningkat pada siklus II yaitu 91,3\% dengan perolehan nilai tertinggi 100 dan nilai terendah 48. Dari data di atas maka dapat disimpulkan implementasi strategi pembelajaran PQ4R mampu meningkatkan kemampuan mengingat mahasiswa pada mata kuliah telaah kurikulum program studi Biologi semester VI B STKIP Bima.
\end{abstract}

Kata Kunci: $P Q 4 R$, Implementasi strategi pembelajaran, Kemampuan mengingat. 


\section{PENDAHULUAN}

Proses belajar mengajar cenderung diartikan sebagai proses penyampaian informasi oleh dosen dan mahasiswa hanya mendengarkan apa yang disampaikan. Namun, sesungguhnya banyak dijumpai kondisi dimana kualitas mahasiswa lebih baik ketika mahasiswa diikutsertakan dalam setiap proses pembelajaran seperti bertanya atau berdiskusi sehingga mahasiswa mendapat banyak kesempatan untuk memanfaatkan pengetahuan baru yang mereka miliki. Dengan demikian, informasi dan pengetahuan baru yang diperoleh oleh mahasiswa bisa diingat secara lebih baik.

Sutikno (2013) pembelajaran tidak akan bermakna jika para siswa tidak termotivasi untuk belajar. Dengan demikian dosen sebagai pendidik harus memiliki kecakapan dalam memotivasi mahasiswa untuk belajar termasuk dengan cara memilih strategi yang tepat. Strategi yang sesuai dengan materi dan kondisi mahasiswa akan lebih efektif menumbuhkan motivasi belajar sehingga mahasiswa lebih semangat untuk ikut serta dalam proses belajar. Keikut sertaan mahasiswa dalam proses belajar berarti dosen sudah berhasil memberikan pengalaman langsung bagi mahasiswa. Melalui pengalaman langsung, mahasiswa akan lebih mudah mengingat materi atau informasi yang diperolehnya.

Kemampuan mengingat dan menyerap mahasiswa juga bergantung pada tingkat konsentrasi seseorang. Seperti yang dikatakan Confucius lebih dari 2400 tahun yang lalu, Confucius menyatakan "what I hear, I forget. what I see, I remember. what I do, I understand".

Silberman (dalam Rusman, 2016) mengemukakan banyak cara yang bisa membuat siswa belajar secara aktif yang disebutnya dengan perlengkapan belajar aktif. Perlengkapan belajar aktif yang dimaksud yaitu: tata letak ruangan kelas, metode mengaktifkan siswa, kemitraan belajar, malakukan analisis terhadap kebutuhan siswa, membangkitkan minat siswa, pemahaman dan melibatkan siswa dalam kegiatan pebelajaran, membentuk kelompok belajar, pemilihan tugas dan strategi yang tepat, menfasilitasi dalam diskusi, kegiatan eksperimen, bermain peran, penghematan waktu, dan pengendalian aktivitas siswa yang berlebihan.

Untuk itu perlu kiranya diterapkan strategi pembelajaran yang mampu membantu meningkatkan kemampuan mengingat mahasiswa. Sehingga dalam proses pembelajaran perlu diterapkan strategi pembelajaran sepesti PQ4R. 
Strategi Preview, Question, Read, Reflect, Recite, dan Review (PQ4R) merupakan strategi yang perlu dimanfaatkan jika ingin memperbaiki kualitas pembelajaran sehingga kualitas mahasiswapun dari segi kemampuan mengingat bisa lebih baik. Menurut Slavin (2008) Strategi PQ4R merupakan strategi studi yang meminta siswa melihat sekilas (preview), menanyakan (question), membaca (read), merenungkan (reflect), mengungkapkan kembali (recite) dan mengkaji ulang (review) bahan.

Mahasiswa memiliki kondisi dan kemampuan mengingat yang berbeda-beda, tergantung pada kemauan dan motivasinya. Kondisi itu pula yang mengharuskan dosen untuk bisa menciptakan kondisi belajar yang menyenangkan dengan cara menentukan strategi pembelajaran yang akan diterapkan secara sepenuhnya atau sebagai pelengkap model pembelajaran yang sudah ada.

Dalam proses belajar mengajar, dosen memegang peranan yang sangat penting. Bukan sekedar menggurui tapi terlebih bagaimana seorang dosen mampu membimbing mahasiswa dengan cara membuat rancangan kegiatan guna mempersiapkan pengalaman belajar yang baik guna mendukung mahasiswa dalam mengingat materi belajar dalam kelas.

Mengingat hal tersebut, strategi pembelajaran sebagai prinsip yang mendasari kegiatan belajar sangat diperlukan. Terutama strategi pembelajaran yang mampu meningkatkan kemampuan mengingat mahasiswa.

\section{METODE PENELITIAN}

Penelitian ini merupakan Penelitian Tindakan Kelas. Dimana tujuannya adalah untuk mengetahui peningkatan kemampuan mengingat pada mahasiswa. Dalam proses belajar mengajar, dosen menggunakan strategi PQ4R sebagai strategi pembelajaran agar proses belajar lebih aktif sehingga kemampuan mengingat mahasiswa meningkat. penelitian tindakan ini dilakasanakan dalam dua siklus, yaitu siklus pertama dan siklus kedua. Subyek penelitian ini adalah mahasiswa semester VI B STKIP Kota Bima, mata kuliah Telaah Kurikulum, dengan jumlah mahasiswa 23 orang.

Data tentang kemampuan mengingat mahasiswa diperoleh dengan menggunakan lembar tes. Kemudian hasil tes dianalisis dengan menghitung ketuntasan individu.

Nilai $=\frac{\sum \text { Jumlah Skor }}{\sum \text { Skor Maksimal }} \times 100 \%$

Mahasiswa dinyatakan tuntas belajar apabila memperoleh nilai $\geq 75$ sesuai dengan Standart Ketuntasan Belajar yang sudah ditetapkan. 
Ketuntasan secara klasikal dihitung dengan rumus sebagai berikut:

Ketuntasan klasikal $=\frac{\sum \text { Siswa yang tuntas belajar }}{\sum \text { Seluruh Siswa }} \times 100 \%$

Indikator ketuntasan belajar mahasiswa secara klasikal apabila 75\% dari seluruh jumlah mahasiswa dinyatakan tuntas belajar.

\section{HASIL DAN PEMBAHASAN}

Dari hasil pengukuran yang dilakukan dengan menggunakan lembar tes terhadap mahasiswa semester VI B mata kuliah telaah kurikulum, dari siklus pertama diperoleh data nilai tertinggi 86 dan nilai terendahnya 34, sedangkan pada siklus kedua diperoleh data nilai tertinggi 100 dan nilai terendahnya 48 .

Evaluasi ketuntasan mahasiswa dilakukan tiap ahir siklus I dan Ahir siklus II. Evaluasi tersebut dilakukan untuk memperoleh data tentang ketuntasan belajar dari segi kemampuan mengingat mahasiswa baik secara individual maupun secara kalasikal. Dari evaluasi tiap ahir siklus I dan II diperoleh data sebagai berikut.

\section{DATA HASIL TES}

Pada siklus I tes diberikan untuk mengetahui kemampuan awal mengingat mahasiswa. Sedangkan pada siklus II tes diberikan untuk mengetahui peningkatan kemampuan mengingat mahasiswa. Tes yang diberikan terdiri dari tes esay dengan jumlah soal 10 nomor untuk masing-masing siklus. Data hasil tes belajar mahasiswa siklus pertama dan kedua dapat dilihat pada tabel berikut.

Tabel 1. Porsentase Ketuntasan Belajar Mahasiswa

\begin{tabular}{lccccc}
\hline & \multicolumn{4}{c}{ Aspek } \\
\cline { 2 - 6 } Hasil Tes & Rata-Rata & $\begin{array}{c}\text { Nilai } \\
\text { Terendah }\end{array}$ & $\begin{array}{c}\text { Nilai } \\
\text { Tertinggi }\end{array}$ & $\begin{array}{c}\text { Jumlah } \\
\text { Ketuntasan } \\
\text { Individu }\end{array}$ & $\begin{array}{c}\text { Persentase } \\
\text { Ketuntasan } \\
\text { Belajar Klasikal }\end{array}$ \\
\hline Siklus I & 66 & 34 & 86 & 10 & $43,40 \%$ \\
Siklus II & 84 & 48 & 100 & 21 & $91,30 \%$ \\
\hline
\end{tabular}

Data pada tabel diatas menjelaskan bahawa pada siklus I jumlah mahasiswa yang tuntas atau mahasiswa yang memperoleh nilai $\geq 75$ adalah 10 orang, sedangkan pada siklus II setelah diterapkannya strategi PQ4R jumlah mahasiswa yang memperoleh nilai $\geq 75$ 
meningkat, yaitu 21 orang. Jadi secara kalasikal ketuntasan pada siklus I belum tercapai, namun pada siklus II ketuntasan klasikal tercapai hingga 91,3\%.

Nilai mahasiswa pada siklus I merupakan nilai yang diperoleh sebelum dosen menerapkan strategi PQ4R, sehingga siswa masih acuh tak acuh untuk ikut berpartisipasi dalam proses perkuliahan. Terutama ketika kegiatan diskusi berlangsung. Mahasiswa enggan untuk bertanya maupun menjawab pertanyaan dari teman atau bahkan dari dosen. Hal tersebut berdampak pada masih banyaknya mahasiswa yang memperoleh nilai dibawah standar ketuntasan yang telah ditentukan, disebabkan karna mahasiswa tidak memperoleh pengalaman secara langsung untuk membuktikan informasi atau pengetahuan yang telah diperoleh sebelumnya, sehingga berdampak pada kurangnya kemampuan mengingat mahasiswa.

Pada siklus II, jumlah mahasiswa yang memperoleh ketuntasan individu mencapai 21 orang, dan ketuntasan klasikal 91,3\%. Penerapan strategi PQ4R atau P singkatan dari preview (membaca selintas dengan cepat), $\mathrm{Q}$ adalah question (bertanya), dan $4 \mathrm{R}$ singkatan dari read (membaca), reflect (refleksi), recite (Tanya jawab sendiri), review (mengulang secara menyeluruh). Strategi PQ4R ini digunakan untuk membantu siswa mengingat apa yang mereka baca atau apa yang mereka dengar ketika proses belajar berlangsung.

Dari paparan data diatas, dapat dikatakan bahwa kemampuan mengingat mahasiswa pada siklus II sangat meningkat dibandingkan pada siklus sebelumnya. Hal tersebut tidak lepas dari pengaruh adanya penggunaan strategi PQ4R sebaga salah satu upaya dosen memperbaiki kualitas belajar agar kualitas mahasiswapun lebih baik.

\section{KESIMPULAN}

Berdasarkan hasil penelitian dan pengolahan data yang telah dilakukan oleh peneliti, maka dapat disimpulkan bahwa terjadi peningkatan kemampuan mengingat mahasiswa setelah mengimplementasikan strategi pembelajaran PQ4R pada mahasiswa STKIP Bima semester VI B mata kuliah telaah kurikulum.

Kemampuan mengingat merupakan hal penting yang harus dimiliki oleh mahasiswa, oleh karenanya dosen perlu memilih dan menerapkan strategi yang tepat untuk mendukung perkembangan kemampuan mengingat mahasiswa. Strategi PQ4R merupakan salah satu strategi yang bisa dijadikan sebagai alternatif dalam proses pembelajaran, baik digunakan sebagai pelengkapa proses pembelajaran yang sudah ada maupun diterapkan secara sepenuhnya. 


\section{DAFTAR PUSTAKA}

Ahmad, F. Z. 2013. Penerapan strategi PQ4R untuk meningkatkan keterampilan membaca pemahaman pada siswa sekolah dasar. Jurnal Pendidikan Sekolah Dasar. 1 (2), hlm. $1-126$.

Aqid, Z. dkk. 2011. Penelitian tindakan kelas. Bandung: Yrama Widya

Usman, M. 2001. Menjadi Guru Profesional. Bandung: PT. Remaja Rosdakarya.

Rusma. 2016. Model-model Pembelajaran (mengembangkan profesonalisme guru). Jakarta: PT. RajaGrafindo Persada

Sutikno, M. S. 2013. Belajar dan Pembelajaran. Lombok: Holistica

Slavin, R. E. 2008. Cooperative Learning (teori, riset dan praktik). Bandung: Nusa Media.

Trianto. 2014. Mendasain model pembelajaran inovatif, progresif, dan kontekstual. Jakarta: Prenadamedia Group.

Wiriatmadja, R. 2012. Metode penelitian tindakan kelas. Bandung: PT Remaja Rosdakarya. 